Check for updates

London

Cite this as: $B M J 2020 ; 370: \mathrm{m} 3030$ http://dx.doi.org/10.1136/bmj.m3030 Published: 30 July 2020

\section{Covid-19: Government failed to protect social care during pandemic, say experts}

\section{Adrian O'Dowd}

The covid-19 pandemic has exposed longstanding failures of successive governments to ensure that the social care sector in England is properly funded, staffed, and stable, concludes a new analysis from a leading think tank.

The Health Foundation published two briefing papers on 30 July analysing the effects of the pandemic on social care users and staff in England ${ }^{1}$ and the policy response so far from the government. ${ }^{2}$ The papers were published just a day after the House of Commons Public Accounts Committee criticised the government for its "inconsistent and at times negligent approach" to social care during the pandemic. ${ }^{3}$

Overall, the Health Foundation authors said that their findings provided more evidence that the government had acted too slowly, provided insufficient support to social care, and given far lower priority to protecting social care than to the NHS. Decades of inaction by successive governments meant that the social care system had entered the pandemic underfunded, understaffed, and at risk of collapse, they said.

They recommended that, for a possible further wave of covid-19, the government should "recognise the interdependency of health and social care" in covid-19 policies and guidance, while tackling an urgent need for fundamental reform of the social care system.

\section{Vulnerable groups}

The analysis showed that policy on social care had focused mostly on care homes and that this risked leaving out other vulnerable groups of users and services, including people receiving domiciliary care.

From 23 March to 19 June of this year more than 30500 excess deaths occurred among care home residents in England and 4500 excess deaths among people receiving domiciliary care, said the authors. This represented a $225 \%$ increase in the death rate among domiciliary care users and a $208 \%$ rise in deaths at care homes, when compared with the same period in the previous three years (2017-19).

March and April saw a substantial reduction in hospital care use among care home residents, as elective admissions decreased to $58 \%$ of previous years and emergency admissions to $85 \%$ of previous years.

By cutting hospital admissions, the authors argued, care homes and NHS teams may have reduced the risk of covid-19 transmission, but the reduced risk of ill health from covid-19 needed to be weighed against the considerable increase in unmet health needs among residents, particularly for elective care.

\section{Investment}

Jennifer Dixon, chief executive at the Health Foundation, said, “The social care system has lacked adequate investment for decades, and successive governments have not faced up to the issues facing the sector. Covid-19 has highlighted the extent of this neglect, with tragic consequences. Against this backdrop, the government's response has been too little and come too late.

"Government must learn now from the first phase of the pandemic to invest in and support social care. In the next year we must see long overdue reform which should include action to improve pay and conditions for staff, stabilise the care provider market, increase access to publicly funded services, and provide greater protection for people against social care costs.”

A Department of Health and Social Care spokesperson said, "The government's priority has always been to ensure everyone gets the care they need throughout this covid-19 pandemic. We have provided specific support to stop the spread of the virus in all registered care homes, but we also recognise the vital importance of protecting those who receive care in their own homes, as well as those who provide home care.

"That is why a quarter of the $€ 600 m$ [€663m; \$779m] Infection Control Fund for Adult Social Care has been allocated to local authorities to support wider workforce resilience, including domiciliary care.

"We have also committed to bringing forward a plan for social care that puts the sector on a sustainable footing and will last long into the future, and the health secretary has initiated cross party talks to seek views from across parliament."

Health Foundation. Adult social care and COVID-19: Assessing the impact on social care users and staff in England so far. 30 Jul 2020. https://www.health.org.uk/adult-social-care-and-covid-19.

2 Health Foundation. Adult social care and COVID-19: Assessing the policy response in England so far. 30 Jul 2020. https://www.health.org.uk/adult-social-careand-covid-19.

3 O'Dowd A. Covid-19: Social care was “thrown to the wolves” by government, say MPs. BMJ2020;370:m3015doi: 10.1136/bmj.m3015. 
This article is made freely available for use in accordance with BMJ's website terms and conditions for the duration of the covid-19 pandemic or until otherwise determined by BMJ. You may use, download and print the article for any lawful, non-commercial purpose (including text and data mining) provided that all copyright notices and trade marks are retained. 